\title{
Ruminta
}

\section{Dampak perubahan iklim pada produksi apel di Batu Malang Impacts of climate change on production of apple in Batu Malang}

Diterima : 15 September 2015/Disetujui : 15 Oktober 2015 / Dipublikasikan : Oktober 2015

CDepartment of Crop Science, Padjadjaran University

\begin{abstract}
Climate change has become an important issue which led to the increase in global temperatures, changes in rainfall patterns, sea level rise, and increased frequency and intensity of extreme weather. Climate change has a significant impact on agriculture, because agriculture has a heavy reliance on climate elements. Associated with it has been studied the impact of climate change on the production of apples in the area of Batu Malang, East Java. The research object wasto determine the impact of climate change on the production of apples and identify adaptation efforts should be done by farmers. The results showed that the area of Batu Malang has experienced climate change. The climate change was not significantaffected on the decreased of apple production. The decreased of apple production in Batu Malang was caused by non-climatic factors such as: apple plants were too old; cultivation of apples was less intensive; conversion of apple crop land; and the price of apples were lower. The most important adaptation to be done by the farmers are the rehabilitation of the apple crops; planting of yield high variety apple that be able to adapt to climate change; and intensify the techniques of apple cultivation.
\end{abstract}

Keywords: Apples $\cdot$ Impacts · Climate change

Sari Perubahan iklim telah menjadi isu penting yang mengakibatkan kenaikan suhu global, perubahan pola curah hujan, kenaikan muka air laut, dan peningkatan frekwensi dan intensitas cuaca ekstrim. Perubahan iklim mempunyai pengaruh signifikan pada bidang pertanian, karena pertanian mempunyai ketergantungan yang kuat terhadap unsur iklim. Terkait dengan hal itu telah dilakukan penelitian dampak perubahan iklim terhadap produksi tanaman

\footnotetext{
Dikomunikasikan oleh F.Y. Wicaksono

Ruminta $^{1}$

${ }^{1}$ Dept. Budadaya Pertanian Fakultas Pertanian Unpad

Korespondensi: r_ruminta@yahoo.com
}

apel di wilayah Batu Malang Jawa Timur. Penelitian bertujuan untuk mengetahui dampak perubahan unsur iklim yaitu temperatur dan curah hujan terhadap produksi apel dan mengidentifikasi usaha adaptasi yang harus dilakukan oleh para petani. Hasil penelitian menunjukkan bahwa wilayah Batu Malang telah mengalami perubahan iklim. Dampak perubahan iklim tersebut terhadap penurunan produksi apel tidak signifikan. Penurunan produksi apel di Batu Malang lebih disebabkan oleh faktor non iklim seperti: tanaman apel sudah berumur tua; budidaya apel kurang intensif; konversi lahan tanaman apel; dan harga apel yang semakin turun. Adaptasi terpenting yang harus dilakukan oleh petani adalah rehabilitasi tanaman apel; menanam bibit apel yang unggul yang mampu beradaptasi dengan perubahan iklim; dan mengintensifkan teknik budidaya apel.

Kata kunci : Apel - Dampak · Perubahan iklim

\section{Pendahuluan}

Perubahan iklim telah menjadi isu penting belakangan iniyang mengakibatkan kenaikan suhu rata-rata global, perubahan pola curah hujan, kenaikan muka air laut, dan peningkatan frekwensi dan intensitas cuaca ekstrim. Hasil kajian Intergovernmental Panel on Climate Change-IPCC (2007) menunjukkan bahwa sudah terjadi perubahan iklim dengan indikasi adanya kenaikan rata-rata temperatur global (periode 1899 hingga 2005 sebesar $\left.0,76{ }^{\circ} \mathrm{C}\right)$; kenaikan muka air laut rata-rata global $(1,8 \mathrm{~mm}$ per tahun dalam rentang waktu antara tahun 1961 sampai 2003); meningkatnya ketidakpastian dan intensitas hujan; meningkatnya banjir, kekeringan dan erosi; dan meningkatnya fenomena cuaca ekstrim seperti El Nino, La Nina, siklon, puting beliung, dan hailstone. Perubahan iklim ini sangat peka terhadap tata air/ sumberdaya air dan pertanian. 
Hasil penelitian perubahan iklim yang dilakukan oleh Syahbuddin et al.. (2004) di 13 stasiun Klimatologi, menegaskan bahwa telah terjadinya perubahan iklim di Indonesia, dimana terdapat tendensi terjadinya peningkatan jumlah curah hujan tahunan di wilayah timur Indonesia, berkisar antara $490 \mathrm{~mm} /$ tahun (Sulawesi Selatan) hingga $1400 \mathrm{~mm} /$ tahun (Jawa Timur). Diikuti oleh peningkatan suhu siang dan malam hari antara $0,5-1,1{ }^{\circ} \mathrm{C}$ dan $0,6-2,3{ }^{\circ} \mathrm{C}$. Sedangkan diwilayah barat Indonesia terjadi sebaliknya, dimana terdapat tendensi penurunan curah hujan tahunan sekitar 135 hingga $860 \mathrm{~mm} /$ tahun, dengan peningkatan suhu siang dan malam hari antara $0,2-0,4{ }^{\circ} \mathrm{C}$ dan $0,2-0,7{ }^{\circ} \mathrm{C}$. Sejalan dengan data-data di atas, tanda-tanda terjadinya perubahan iklim global tersebut juga terlihat dari makin cepatnya periode El-Nino menerpa Indonesia yang semula terjadi untuk 56 tahun sekali, menjadi 2-3 tahun sekali (Mantom, et al., 2001).

Hasil penelitian perubahan iklim lainnya di wilayah Sumatera Selatan menunjukkan telah terjadi peningkatan suhu udara sebesar 0,4 hingga $0,6{ }^{\circ} \mathrm{C}$. Sementara itu, curah hujan mengalami penurunan sebesar 0 hingga $197 \mathrm{~mm}$ di wilayah tersebut. Adanya perubahan curah hujan dan suhu udara tersebut berpengaruh juga terhadap perubahan hitergraf dan klasifikasi Oldeman di wilayah tersebut yang cenderung bersifat lebih kering. Perubahan iklim tentu menpunyai dampak yang signifikan terhadap ketersediaan air tanaman, musim tanam, awal tanam, dan teknik budidaya tanaman pada suatu lahan (Ruminta dan Handoko, 2011a).

Hasil penelitian perubahan iklim di Wilayah Malang Raya Jawa Timur menunjukkan bahwa suhu udara meningkat sebesar 0,7 hingga $0,8{ }^{\circ} \mathrm{C}$ dan curah hujan menurun sebesar 0-550 mm. Pola hitergraf di wilayah Malang Raya juga mengalami perubahan atau pergeseran. Demikian juga klasifikasi Oldeman di wilayah tersebut juga mengalami perubahan umumnya dari kelas C3 menjadi C2 (Ruminta dan Handoko, 2011b).

Adanya perubahan iklim tersebut mengancam produksipertanian termasuk produksi tanaman apel dan oleh karena itu juga mengancam mata pencaharian petani yang bergantung pada pertanian tersebut. Pertanian tanaman apel adalah sektor yang cukup rentan terhadap perubahan iklim karena ketergantungan tinggi pada iklim dan cuaca. Apel dapat tumbuh dan berbuah baik di daerah dataran tinggi yang memiliki temperatur rendah. Tanaman apel menghendaki lingkungan dengan karakteristik yaitu temperatur rendah, kelembaban udara rendah dan curah hujan tidak terlalu tinggi (Soelarso, 1996). Sampai saat ini belum banyak daerah yang mengembangkan tanaman ini secara luas.Salah satu daerah tersebut adalah kawasan Malang Propinsi Jawa Timur, dimana sentra produksinya terletak di kota Batu dan Kecamatan Poncokusumo.Di daerah tersebut, perkebunan apel telah diusahakan sejak tahun 1950 dan berkembang pesat pada tahun 1990-an hingga saat ini.

Namun beberapa tahun terakhir ini telah terjadi penurunan produksi apel Batu Malang. Menurunnya produksi apel disebabkan banyak petani yang gagal panen akibat perubahan iklim dan faktor non-iklim. Hasil panen apel Batu Malang saat ini jauh dari hasil panen saat kondisi tahun 1990-an. Petani apel menilai bahwa kegagalan panen beberapa tahun ini disebabkan terjadinya perubahan iklim yaitu hujan yang terus menerus (Sitompul, 2007; Rahayu dan Muhandoyo, 2011). Terkait dengan isu tersebut perlu dilakukan penelitian untuk menjawab secara pasti sejauh mana terjadinya perubahan iklim di wilayah kota Batu Malang, bagaimana pola hubungan produksi apel Batu Malang dengan iklim; apakah isu penurunan produksi apel Batu Malang hanya semata-mata akibat perubahan iklim; dan apa pilihan adaptasi strategis untuk mengatasi penurunan produksi apel batu Malang.

Tujuan dari penelitian ini yaitu mengkaji sejauh mana terjadinya perubahan iklim di wilayah kota Batu Malang, mengetahui bagaimana pola hubungan produksi apel kota Batu dengan iklim; mengkaji isu penurunan produksi apel Batu Malang akibat perubahan iklim; dan mengidentifikasi pilihan adaptasi strategis penurunan produksi apel batu Malang.

\section{Bahan dan Metode}

Penelitian dampak perubahan iklim terhadap produksi apel dilakukan di pusat produksi apel kota Batu Malang Jawa Timur. Penelitian dilaksanakan pada tahun 2012. Penelitian ini menggunakan metode deskriptif eksplanatif. Penelitian menggunakan data hasil observasi langsung dan data historis (sekunder) terkait dengan data iklim dan data apel Batu Malang. 
Analisis dan interpretasi data penelitian menggunakan software Minitab 18 dan Mathlab 2008R.

\section{Hasil dan Pembahasan}

Analisis Perubahan Iklim di Kota Batu Malang. Berdasarkan analisis data temperatur dan curah hujan dari 1981 hingga 2030 (Skenario SRA1B), wilayah kota Batu akan mengalami perubahan iklim hingga tahun 2030 seperti ditunjukkan pada Tabel 1. Demikian juga untuk hitergraf, wilayah kota Batu akan mengalami perubahan hitergraf seperti ditunjukkan pada Gambar 1. Secara umum temperatur akan sedikit mengalami peningkatan sementara itu curah hujan juga telah mengalami peningkatan. Rerata temperatur dan curah hujan masingmasing meingkat dari $21,8{ }^{\circ} \mathrm{C}$ menjadi $22,3{ }^{\circ} \mathrm{C}$ dan dari $2327 \mathrm{~mm}$ menjadi $2941 \mathrm{~mm}$ per tahun. Sementara itu untuk tipe iklim berdsarkan Klasifikasi Schmidth-Ferguson juga mengalami perubahan dari tipe iklim C (iklim sedang) menjadi tipe iklim A (iklim basah) Adanya perubahan iklim tersebut sampai batas tertentu akan mempengaruhi produksi pertanian termasuk produksi apel di kota Batu.

Tabel 3. Perubahan Iklim di Kota Batu Malang.

\begin{tabular}{lcc}
\hline \hline \multirow{2}{*}{\multicolumn{1}{c}{ Indikator Iklim }} & \multicolumn{2}{c}{ Perubahan Iklim } \\
\cline { 2 - 3 } & $\begin{array}{c}\text { Periode } \\
1999-2010\end{array}$ & $\begin{array}{c}\text { Periode } \\
2011-2030\end{array}$ \\
\hline Rerata Temperatur $\left({ }^{\circ} \mathrm{C}\right)$ & 21,8 & 22,3 \\
Temperatur Maks. $\left({ }^{\circ} \mathrm{C}\right)$ & 22,5 & 22,8 \\
Temperatur Min. $\left({ }^{\circ} \mathrm{C}\right)$ & 20,8 & 21,2 \\
Jumlah Curah Hujan $(\mathrm{mm})$ & 2327 & 2941 \\
Curah Hujan Maks. $(\mathrm{mm})$ & 325 & 393 \\
Curah Hujan Min. $(\mathrm{mm})$ & 10 & 68 \\
Bulan Basah & 7 & 10 \\
Bulan Kering & 4 & 0 \\
Tipe Hujan Klasifikasi & & \\
Schmidth-Ferguson & $\mathrm{C}$ & $\mathrm{A}$ \\
\hline Sumber: Ruminta dan Handoko &
\end{tabular}

Sumber : Ruminta dan Handoko (2011)

Berdasarkan kajian terhadap data BMKG Karangploso mencatat, pada 1991, temperatur rata-rata mencapai $22,9-28,3{ }^{\circ} \mathrm{C}$, yang selanjutnya terus naik menjadi $22,96-28,6{ }^{\circ} \mathrm{C}$ pada 1993. Pada 1994, temperatur turun menjadi 22,56-26 ${ }^{\circ} \mathrm{C}$, tapi kemudian naik drastis pada 1998 yang mencapai $23,8-27,3{ }^{\circ} \mathrm{C}$. Pada 2008, temperatur turun lagi hingga mencapai 22,97-28,6 ${ }^{\circ} \mathrm{C}$, namun naik kembali menjadi $23,6-27,5{ }^{\circ} \mathrm{C}$ pada 2009. Adapun kelembapan udara naik dari 16-27 persen pada 1999 menjadi 20-31 persen pada 2009 (BMKG, 2010).

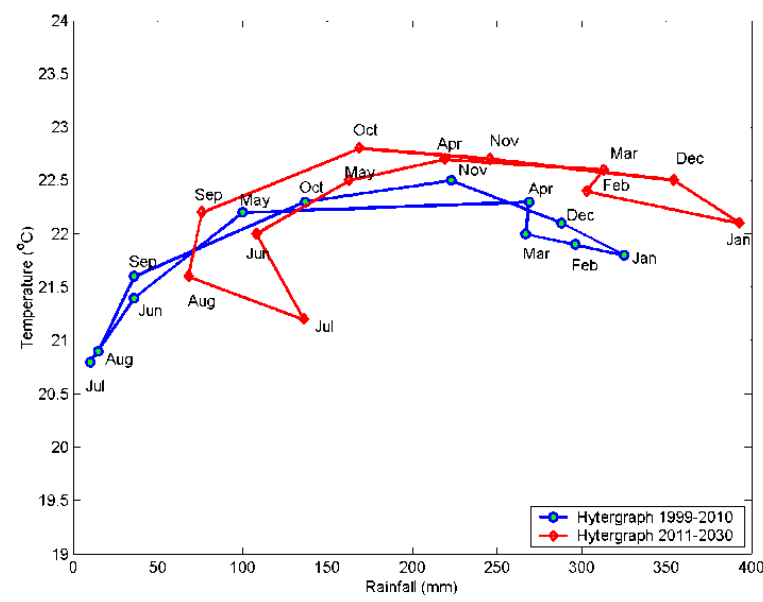

Gambar 1. Perubahan Hitergraf Kota Batu Malang

Produksi Apel dan Kaitannya dengan Iklim. Produksi apel sangat dipengaruhi oleh teknik budidaya, kesuburan tanah, pengendalian hama dan penyakit tanaman, pengendalian gulma, dan kondisi iklim. Unsur iklim yang sangat mempengaruhi produksi apel adalah temperatur dan curah hujan. Tanaman apel menghendaki temperatur rendah dan curah hujan yang tidak terlalu tinggi. Adanya perubahan temperatur dan curah hujan di wilayah kota Batu sangat berpotensi terhadap perubahan produksi apel di wilayah tersebut.

Produksi apel di kota Batu mengalami perubahan dari waktu ke waktu seperti ditunjukan pada Tabel 2 dan Gambar 2 hingga Gambar 5. Selama periode 1999 hingga 2010 produktivitas apel berkisar antara 10,9 $\mathrm{kg} /$ pohon (tahun 2002) hingga $58,6 \mathrm{~kg} /$ pohon (tahun 2009). Sementara itu produksi apel kota Batu berkisar antara 172,489 kwintal (tahun 2002) hingga 2.097.514 kwintal (tahun 2006). Berdasarkan data tersebut menunjukkan bahwa selama periode 1999 hingga 2010 produktivitas apel di kota Batu tidak bisa dikatakan turun atau naik. Jadi selama ini ada isu bahwa produktivitas apel mengalami penurunan tidak seluruhnya betul. 
Tabel 2. Data Produksi Apel, Temperatur, dan Curah Hujan Kota Batu Malang.

\begin{tabular}{cccccc}
\hline \hline Tahun & Jumlah Pohon Apel & $\begin{array}{c}\text { Produksi Apel } \\
(\mathbf{k w})\end{array}$ & $\begin{array}{c}\text { Produktivitas Apel } \\
(\mathbf{k g} / \mathbf{p o h o n})\end{array}$ & $\begin{array}{c}\text { Temperatur } \\
\left({ }^{\circ} \mathbf{C}\right)\end{array}$ & $\begin{array}{c}\text { Curah Hujan } \\
(\mathbf{m m})\end{array}$ \\
\hline 1999 & 1.802 .717 & 461.895 & 19,6 & 21,4 & 2171 \\
2000 & 2.874 .753 & 522.433 & 37,3 & 21,4 & 2007 \\
2001 & 3.452 .010 & 450.268 & 13,4 & 21,5 & 1924 \\
2002 & 1.471 .760 & 172.489 & 10,9 & 21,9 & 1878 \\
2003 & 1.539 .842 & 272.933 & 14,6 & 22,0 & 1838 \\
2004 & 1.707 .052 & 674.313 & 45,9 & 21,9 & 2081 \\
2005 & $4.685,468$ & 1.628 .316 & 38,4 & 22,2 & 1897 \\
2006 & 4.091 .321 & 2.097 .514 & 42,7 & 22,1 & 1643 \\
2007 & 4.035 .058 & 611.000 & 14,0 & 21,3 & 2101 \\
2008 & 4.349 .203 & 1.230 .079 & 28,8 & 21,8 & 1912 \\
2009 & 3.608 .375 & 1.690 .736 & 58,6 & 22,0 & 1726 \\
2010 & 1.974 .366 & 842.799 & 17,0 & 22,3 & 3344 \\
\hline \hline
\end{tabular}

Sumber : Dinas Pertanian Kota Batu (2010); BPS Malang (2010); dan BKG Malang (2010).

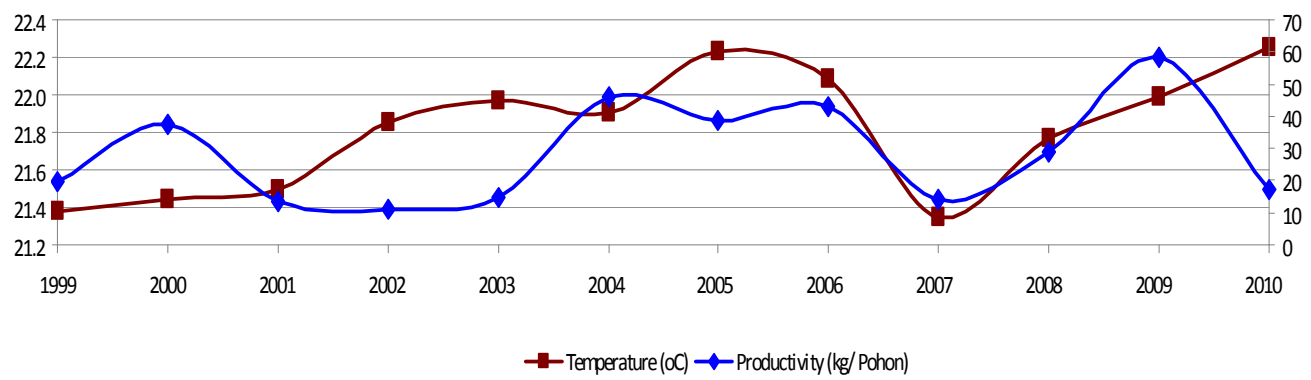

Gambar 2. Pola Poduktivitas Apel dan Temperatur Kota Batu Malang.

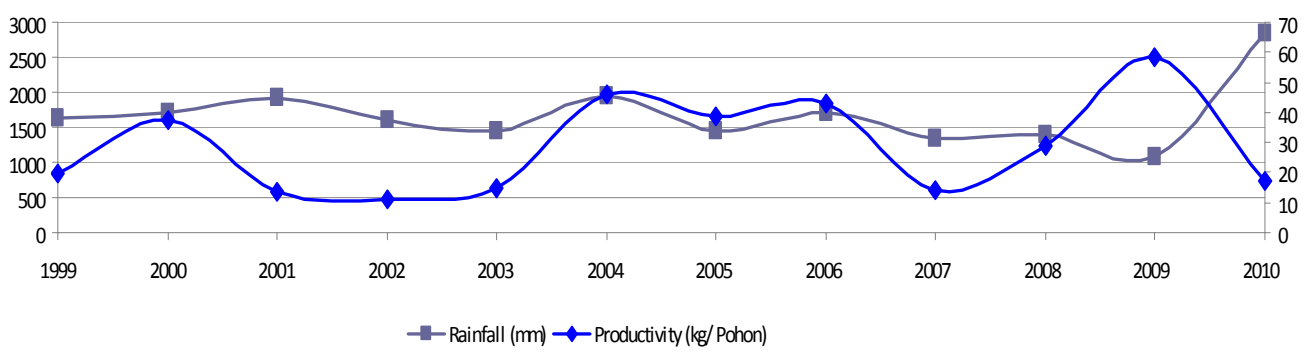

Gambar 3. Pola Poduktivitas Apel dan Curah Hujan Kota Batu Malang.

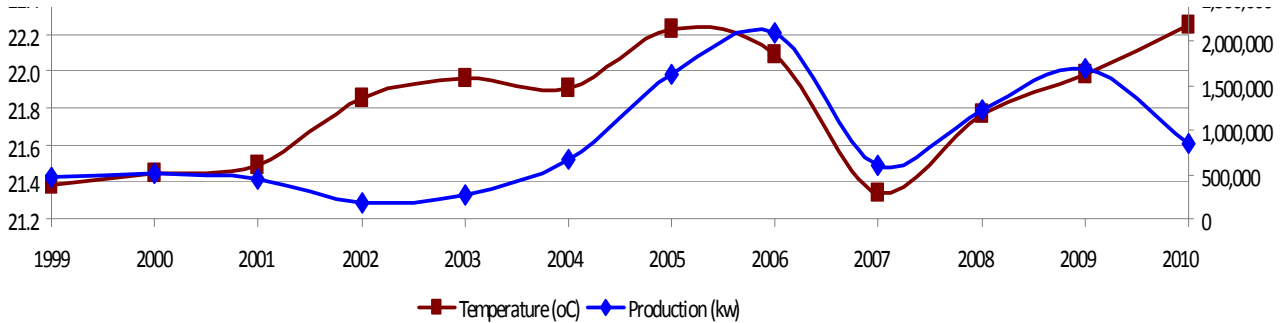

Gambar 4. Pola Poduksi Apel dan Temperatur Kota Batu Malang.

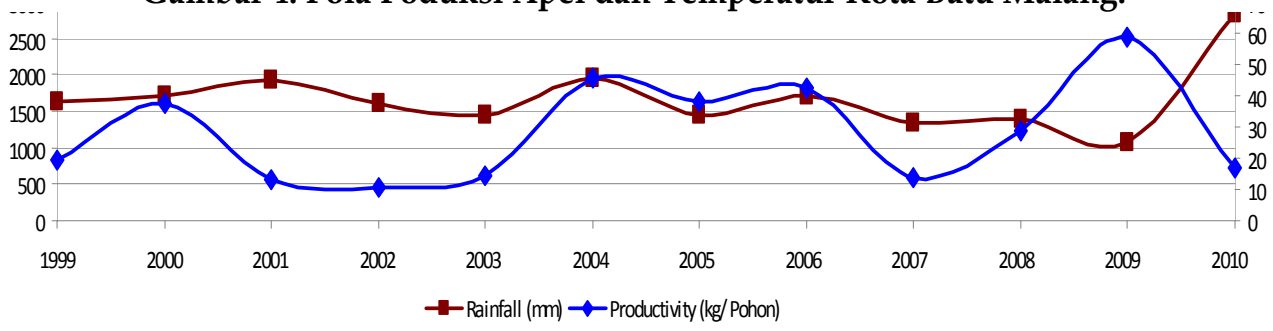

Gambar 5 Poduksi Apel dan Curah Hujan Kota Batu Malang. 
Model Hubungan Produktivitas Apel dan Iklim di Kota Batu Malang. Hubungan produktivitas apel dengan temperatur dan curah hujan di kota Batu sesunggunya tidak begitu kuat seperti ditunjukkan pada Tabel 3. Korelasi antara produktivitas dan produksi apel dengan temperatur bernilai positif. Hal ini menunjukkan bahwa sampai batas tertentu (hingga sekitar 22,2 $\left.{ }^{\circ} \mathrm{C}\right)$ meningkatknya temperatur dapat meningkatkan produktivitas tanaman apel seperti ditunjukkan pada Gambar 6 dan 7. Namun jika peningkatan temperatur terus berlanjut hingga di atas temperatur tersebut maka produksi tanaman apel akan levelling off (produktivitas tidak naik lagi) atau bahkan produksinya menjadi turun. Berdasarkan Gambar 7, temperatur optimum untuk produktivitas tanaman apel di kota Batu adalah $22,2{ }^{\circ} \mathrm{C}$.

Sementara itu hubungan produktivitas dan produksi dengan curah hujan bernilai negatif, hal ini menunjukkan bahwa makin tinggi curah hujan menyebabkan penurunan produktivitas tanaman apel di kota Batu seperti ditunjukan pada Gambar 6 dan 8. Makin tinggi curah hujan menyebabkan bunga dan buah muda gugur serta hama dan penyakit tanaman apel berkembang pesat sehingga produksi apel menjadi berkurang. Berdasarkan model hubungan produktivitas apel dengan curah hujan dapat diidentifikasi bahwa curah hujan terbaik untuk produktivitas apel terbaik berada pada kisaran curah hujan 2200 hingga $2800 \mathrm{~mm}$ per tahun.

Tabel 3. Korelasi Produktivitas dan Produksi Apel dengan Temperatur dan Curah Hujan Kota Batu.

\begin{tabular}{lcc}
\hline \hline Komponen & Temperatur & $\begin{array}{l}\text { Curah } \\
\text { Hujan }\end{array}$ \\
\hline Produksi apel & 0,579 & $-0,239$ \\
Produktivitas apel & 0,346 & $-0,339$ \\
\hline \hline
\end{tabular}

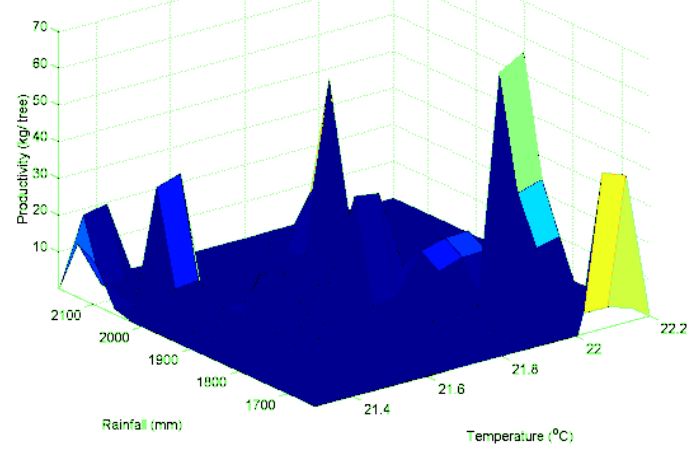

Gambar 6. Hubungan antara Produktivitas Apel dengan Temperatur dan Curah Hujan di Kota Batu Malang.

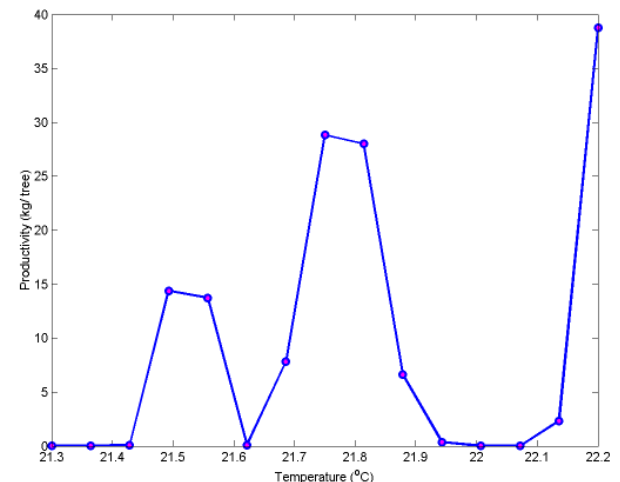

Gambar 7. Hubungan antara Produktivitas Apel dengan Temperatur Kota Batu Malang.

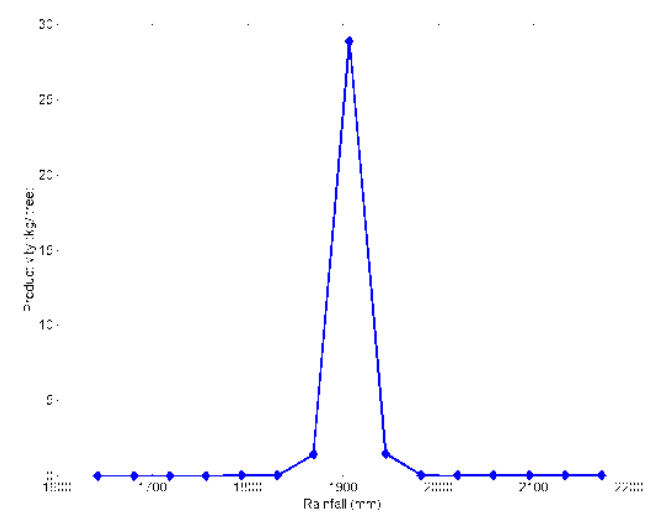

Gambar 8. Hubungan antara Produktivitas Apel dengan Curah Hujan Kota Batu Malang.

Penurunan Produksi Apel di Kota Batu. Perkebunan apel mengalami masa kejayaan pada 1980-an hingga 1996. Menurut catatan Dinas Pertanian dan Kehutanan Kota Batu, total luas lahan perkebunan apel di kota Batu pada 1980 mencapai 2.015 hektare, dengan jumlah produksi per tahun sebesar 72 ribu ton yang bersumber dari 5,64 juta pohon apel. Karena itulah, apel pun dijadikan maskot kota Batu (Badan Perencanaan Pembangunan Daerah Malang, 2009).

Kecamatan Bumiaji menjadi sentra tanaman apel dibandingkan dua kecamatan lain di kota Batu, yakni Junrejo dan Batu. Namun luas lahan apel dari tahun ke tahun terus menyusut. Data pada tahun 2009 menyebutkan bahwa luas lahan apel tinggal 600 hektare, dengan jumlah pohon apel sebanyak 2.506.546 yang hanya menghasilkan 24.625 ton per tahun. Berdasarkan penelitian Dinas Pertanian pada tahun 2009 menyimpulkan bahwa banyaknya kerusakan hutan di kota Batu (seperti di desa Bumiaji, Sidomulyo, dan Punten) telah menyebabkan kenaikan temperatur, perubahan kelembaban udara yang kemudian berdampak pada penu-runan produksi tanaman apel (Dinas Pertanian Kota Batu, 2010). 
Di lain pihak, berdasarkan data produksi apel serta temperatur dan curah hujan selama 1999 hingga 2010 (Tabel 1) menunjukkan bahwa isu penurunan produksi apel sebagai akibat dari naiknya temperatur atau perubahan iklim tidak sepenuhnya betul. Berdasarkan pengamatan di lapangan penurunan produksi apel tersebut lebih disebabkan oleh faktor-faktor sebagai berikut : (a) Adanya konversi lahan tanaman apel menjadi lahan tanaman lain (non apel); (b) Tanaman apel yang masih ada sudah berumur tua sehingga kurang produktif lagi; (c) Budidaya apel menjadi kurang intensif lagi sehingga banyak tanaman apel tidak terpelihara lagi; dan (d) Petani apel tidak bersemangat lagi membudidayakan tanaman apel karena harga apel Batu yang semakin turun akibat kurang kompetitif terhadap banyaknya buah apel impor membanjiri pasar.

Potensi Produksi Apel Batu di Masa Datang. Berdasarkan proyeksi iklim kota Batu pada tahun 2030 (seperti ditunjukkan pada Tabel 1 dan Gambar 1), produksi apel di kota Batu berpotensi dapat mengalami penurunan di masa mendatang akibat kenaikan temperatur dan peningkatan curah hujan di kota Batu hingga tahun 2030. Kenaikan temperatur sehingga berada di atas temperatur optimum produksi apel dapat menyebabkan levelling off seperti ditunjukkan pada Gambar 7. Sementara itu peningkatan curah hujan akan menyebabkan proses pembungaan apel terganggu dan buah apel muda akan rontok sehingga menurunkan produksi apel (Gambar 8). Di samping itu peningkatan curah hujan menyebabkan peningkatan kelembaban udara sehingga sangat berpotensi bagi berkembangnya hama dan penyakit yang mengancam produksi tanaman apel. Hal ini tidak berbeda dengan hasil kajian Rahayu dan Muhandoyo (2011) bahwa temperatur udara, kelembaban, dan curah hujan mempengaruhi produktivitas tanaman apel di Kecamatan Poncokusumo Malang.

Namun demikian penurunan produksi apel Batu akibat perubahan temperatur dan curah hujan tersebut tidak akan tidak terlalu drastis dibanding penurunan produksi akibat faktor non-iklim seperti konversi lahan tanaman apel menjadi lahan usaha lain dan persaingannya dengan apel impor.

Strategi Adaptasi untuk Mengantisipasi Penurunan Produksi Apel Batu. Penurunan produksi apel di kota Batu akibat berbagai faktor seperti dijelaskan di atas perlu dicegah sehingga ikon Bota Batu sebagai pusat Apel di Indonesia bisa dipertahankan. Ada beberapa strategi untuk mencegah terjadinya penurunan produksi apel kota Batu yaitu (Tim Sintesis Kebijakan BBSDLP, 2008; Ruminta dan Handoko, 2011; Mayasari dan Suroso, 2011): (a) Merevitalisasi penggunaan lahan tanaman apel berdasarkan keseuaian tanaman apel dengan kondisi lingkungannya; (b) Menanam bibit apel yang unggul yang mampu beradaptasi dengan perubahan iklim, terutama perubahan temperatur dan curah hujan; (c) Mengintensifkan teknik budidaya apel yang berorientasi pada pertanian yang berkelanjutan; (d) Meningkatkan efisiensi penggunaan pupuk dan pestisida yang mengarah pada upaya konservasi lahan dan pertanian ramah lingkungan; (e) Merehabilitasi penanaman apel dengan cara mengganti tanaman apel yang sudah tua oleh tanaman apel muda; (f) Mencegah konversi lahan tanaman apel menjadi lahan tanaman non apel, bahkan lahan non-pertanian; dan (g) Memberikan insentif bagi petani tanaman apel sehingga petani tetap bergairah menanan apel dan tidak beralih profesi menjadi petani non apel. Insentif tersebut dapat berupa bantuan promosi, bantuan teknis untuk mengurangi biaya produksi terutama pupuk, serta intervensi pasar untuk menaikkan harga jual.

\section{Kesimpulan dan Saran}

\section{Kesimpulan}

1. Sampai batas tertentu wilayah sentra produksi apel kota Batu Malang telah mengalami perubahan iklim.

2. Dampak perubahan iklim terhadap penurunan produksi apel di Batu Malang tidak signifikan.

3. Penurunan produksi apel di Batu Malang lebih disebabkan oleh faktor non iklim seperti: konversi lahan tanaman apel; tanaman apel sudah berumur tua; budidaya apel kurang intensif; dan harga apel Batu yang semakin turun.

4. Penurunan produksi apel Batu Malang di masa datang akibat perubahan iklim tidak terlalu drastis dibanding penurunan produksi akibat faktor non-iklim.

Saran. Ada beberapa strategi untuk mencegah terjadinya penurunan produksi apel kota Batu yaitu:

1. Mencegah konservasi lahan dan merevitalisasi penggunaan lahan tanaman apel.

2. Merehabilitasi penanaman apel dan menanam bibit apel yang unggul yang mampu beradaptasi dengan perubahan iklim. 
3. Mengintensifkan teknik budidaya apel.

4. Memberikan insentif bagi petani tanaman apel.

5. Menekan masuknya apel dari luar negeri.

\section{Daftar Pustaka}

Bappeda Malang. 2009. Rancangan Bangun Pengem-bangan Agribisnis Apel di Kota Batu. Batu Malang.

BMKG Malang. 2010. Data Iklim Kota Batu Malang. Batu Malang.

BPS Malang. 2010. Kota Batu Dalam Angka Tahun 2010. Batu Malang

Dinas Pertanian Kota Batu. 2009. Laporan Statistik Pertanian Kota Batu. Tahun 2009. Batu Malang.

Dinas Pertanian Kota Batu. 2010. Laporan Tahunan Dinas Pertanian Kota Batu Tahun 2010. Batu Malang.

IPCC, 2007. Climate Change 2007-Impacts, Adaptation and Vulnerability. Contribution of Working Group II to the Fourth Assessment Report of the IPCC. Cambridge University Press. New York.

Mantom,M.J., P.M. Della-Marta, M.R. Haylock, K.J. Hennessy, N. Nicholls, L.E. Chambers, D.A. Collins, G Daw. 2001: Trends in extreme daily rainfall and temperature in Southeast Asia and the South Pacific; 19611998. Int. J. Climatol. 21:269-284.

Mayasari, S. P. dan D. S. A. Suroso. 2011. Identifikasi opsi adaptasi perubahan iklim bagi petani apel di kota Batu (Studi kasus :
Desa Bumiaji). Jurnal Perencanaan Wilayah dan Kota. A SAPPK, Vol.01, No.02.

Rahayu, J, dan Muhandoyo. 2011. Dampak perubahan iklim terhadap usaha apel di Kecamatan Poncokusumo Kabupaten Malang. Laporan Penelitian. Faperta Univ. Wisnuwadhana.

Ruminta dan Handoko. 2011a. Kajian risiko dan adaptasi perubahan iklim pada sektor pertanian di Sumatera Selatan. Laporan Penelitian. KLH Jakarta

Ruminta dan Handoko. 2011b. Kajian risiko dan adaptasi perubahan iklim pada sektor pertanian di Malang Raya. Laporan Penelitian. KLH Jakarta

Syahbuddin, H., Manabu D. Yamanaka, and Eleonora Runtunuwu. 2004. Impact of climate change to dry land water budget in Indonesia: observation during 1980-2002 and simulation for 2010-2039. Graduate School of Science and Technology. Kobe University.

Sitompul, S.M. 2007. Kendala Produktivitas tanaman apel (Malus sylvestris Mill) di wilayah Malang Raya. Seminar hasil penelitian PHK A2, Jur. Budidaya Pertanian, Faperta Unibraw. Malang

Soelarso, R.B. 1996. Budidaya Apel, Kanisius. Yogyakarta.

Tim Sintesis Kebijakan Balai Besar Sumber Daya Lahan Pertanian (BSDLP), 2008. Dampak perubahan iklim terhadap sektor pertanian, serta strategi antisipasi dan teknologi adaptasi. Pengembangan Inovasi Pertanian 1(2):138-140 